\title{
Dr. John C. ReED, JR.: PiOneERING GeOlogist, MOUNTAINEER, AND AUTHOR OF CREATION OF THE TETON LANDSCAPE
}

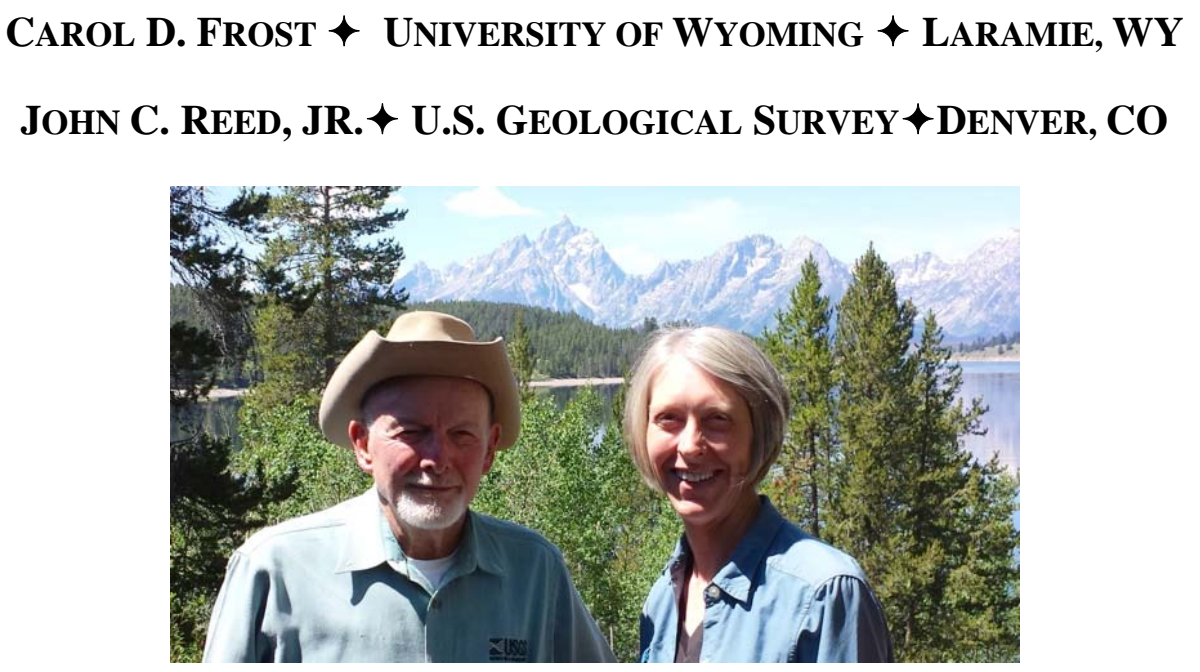

The principal investigators on Jackson Lake, July 2013. Left: Jack Reed; Right: Carol Frost

\begin{abstract}
$\uparrow \quad$ ABSTRACT
Few geologists today possess the mountaineering skills to study rocks exposed in the topographically challenging terrain of the Tetons. Even fewer can claim the accomplishment of making the first geologic map of an entire mountain range. One of these pioneering geologists is John C. Reed, Jr., who joined the U.S. Geological Survey in 1953, and who is now scientist emeritus at the U.S. Geological Survey in Denver (Figure 1). In addition to his field geology expertise, Dr. Reed also has a special talent for communicating complex geologic concepts to the public. The purpose of this project was to profile this pioneering mountaineer-geologist and accomplished writer, and to archive his maps, field notes, and photographs for use by future scientists and for the public, particularly park visitors.
\end{abstract}

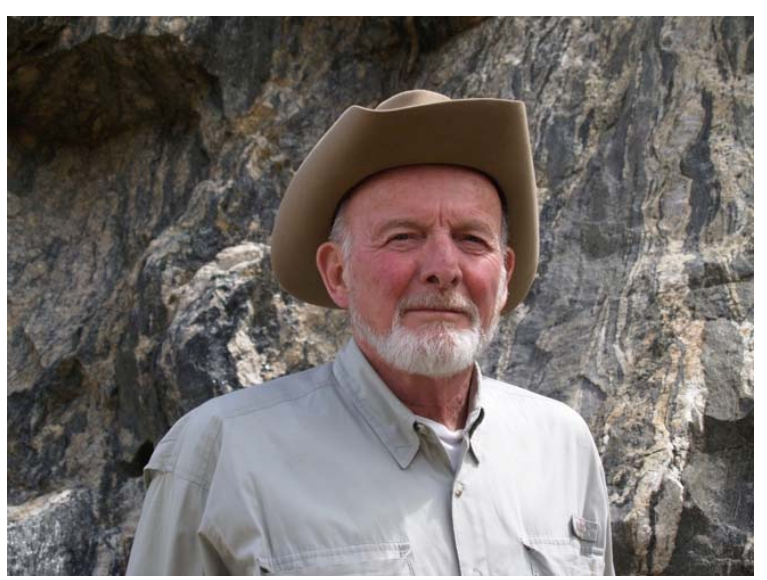

Figure 1. Jack Reed

The products of this project include:

- A bibliography of Dr. Reed's publications on the geology of Grand Teton National Park (see Appendix). 
- Oral histories of Dr. Reed's experiences doing geologic mapping in the park. Video recording was done of Dr. Reed and his wife Linda in July 2013 on site in Grand Teton National Park. From the recordings, four edited, approximately 4-6 minute segments were produced on the geology of the Teton Range, the Teton Glacier, the process of making the geologic map, and the life of the field base camp manager. These have been accessioned into the University of Wyoming American Heritage Center John C. Reed Collection (\#12585).

- A profile by Dr. Reed entitled "Thinking back through a lifetime in the U.S. Geological Survey" will be published in the fall 2014 issue of Rocky Mountain Geology. The article includes a summary of Dr. Reed's scientific contributions to Teton geology by Carol Frost.

- Archival quality digital copies of Dr. Reed's bibliography, CV, and Teton field maps, field notebooks, photographs, and $35 \mathrm{~mm}$ slides have been made and have been accessioned into the University of Wyoming American Heritage Center John C. Reed Collection (\#12585).

\section{INTRODUCTION}

In 1962, when Jack Reed (John C. Reed, Jr.) began his geologic map of the Teton Range, little was known about these basement rocks. Members of the Hayden Surveys had noted their metamorphic character (Bradley 1873, St. John 1879), Horberg and Fryxell (1942) had identified scattered occurrences of metasedimentary rock within the gneisses that compose the high peaks, and Bradley (1956) had published a structure map of Buck Mountain area, but large tracts of the scenic mountain peaks and canyons remained to be explored and described. The U.S. Geological Survey made an excellent choice in assigning Jack to map the Precambrian rocks: not only was he an experienced field geologist but also an accomplished mountaineer and climber who'd first summited the Grand and Middle Tetons in 1953. In the course of his geologic mapping Reed would pioneer routes and make first ascents of eleven peaks in the northern part of the range (Ortenburger and Jackson 1996) (Figure 2). He also contributed the chapter on Teton geology in Ortenburger's "Climber's Guide to the Teton Range."

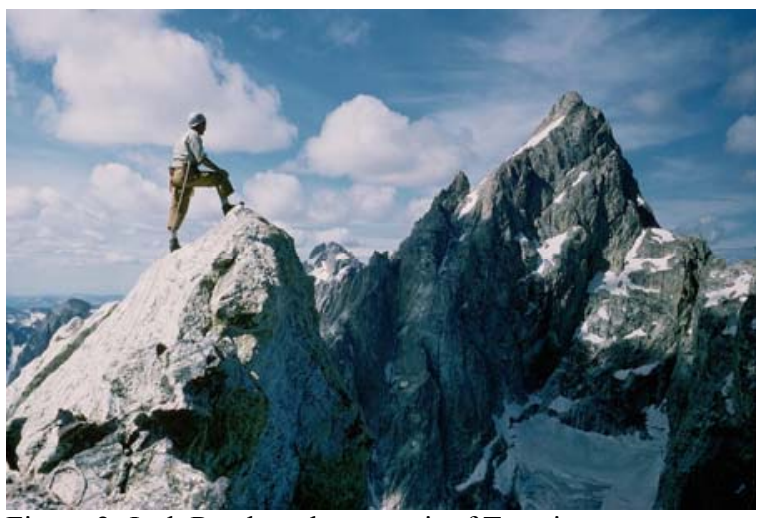

Figure 2. Jack Reed on the summit of Teewinot.

Jack accomplished the majority of the fieldwork for his geologic map during the summers of 1962,1963 , and 1964, working systematically from north to south. In 1962 he and field assistant Jim Dieterich mapped from Webb Canyon south to Snowshoe Canyon, including Rolling Thunder Mountain, Ranger Peak, and Eagles Rest Peak (Reed 1963). They also surveyed a small area in the vicinity of Lake Solitude and Petersen glacier. In 1963 he and Dave Steller examined and mapped the rocks from Waterfall to Leigh Canyons, including Mount Moran. The area mapped by Jack and his assistant Don Coates in July and August 1964 extended from Paintbrush Canyon to the mountains south of Granite Canyon in the southern part of the range (Figure 3). That fall, he and Don took a series of low altitude oblique stereoscopic aerial photographs that Jack used to help delineate the granite and pegmatite dikes that intrude the older gneissic rocks and to map the sedimentary rocks on the western flanks of the range. In 1965 he and J. David Love returned to the northern part of the Tetons to map in the area of Owl and Berry Creeks, and in 1966 Reed worked in the high country west of the Cathedral Peaks. Finally in 1970, working with Rob Blair, Jack completed the mapping project with geologic fieldwork in the northwestern part of the range. His field notebooks, field map sheets, and photographs record over 1200 sites where he made geologic and structural observations. These data formed the basis of his portion of the final geologic map for Grand Teton National Park, an area in excess of 186 square miles of spectacularly rugged terrain (Love et al. 1992).

Jack's wife Linda spent some time each season in the Teton Range with her husband. An experienced climber herself, she accompanied Jack on some of his traverses in the first years before their daughter and son were born (Figure 4). Later she managed the base camps at Taggart Creek and on Jackson Lake while looking after their children. 


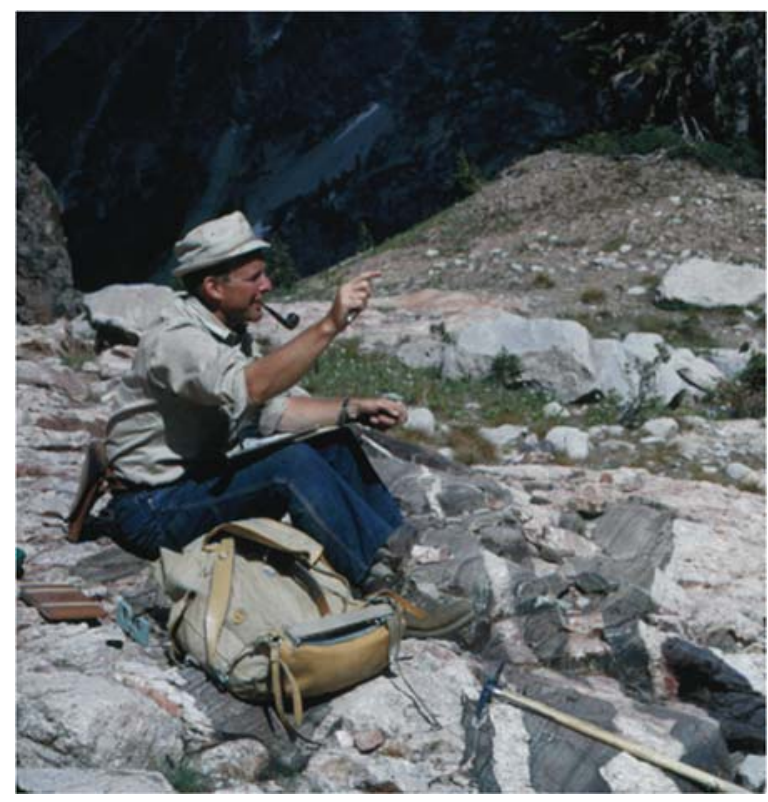

Jack's scientific investigations of the Teton Range were not limited to geologic mapping of the Precambrian rocks. He took time during the field seasons in 1962-1966 to survey and resurvey markers placed across the Teton Glacier to document the rate of ice movement and changes in ice thickness (Reed 1965) (Figures 5-7). Later he and R.E. Zartman conducted the first $\mathrm{K}-\mathrm{Ar}, \mathrm{Rb}-\mathrm{Sr}$, and $\mathrm{U}-\mathrm{Pb}$ age determinations on the Precambrian rocks of the Teton Range (Reed and Zartman 1973). Along with these scientific pursuits, he and J. David Love, later joined by Kenneth Pierce, wrote the beautifully illustrated popular book, "Creation of the Teton Landscape," for a general audience.

Figure 3. Jack Reed on the outcrop in the Teton Range.

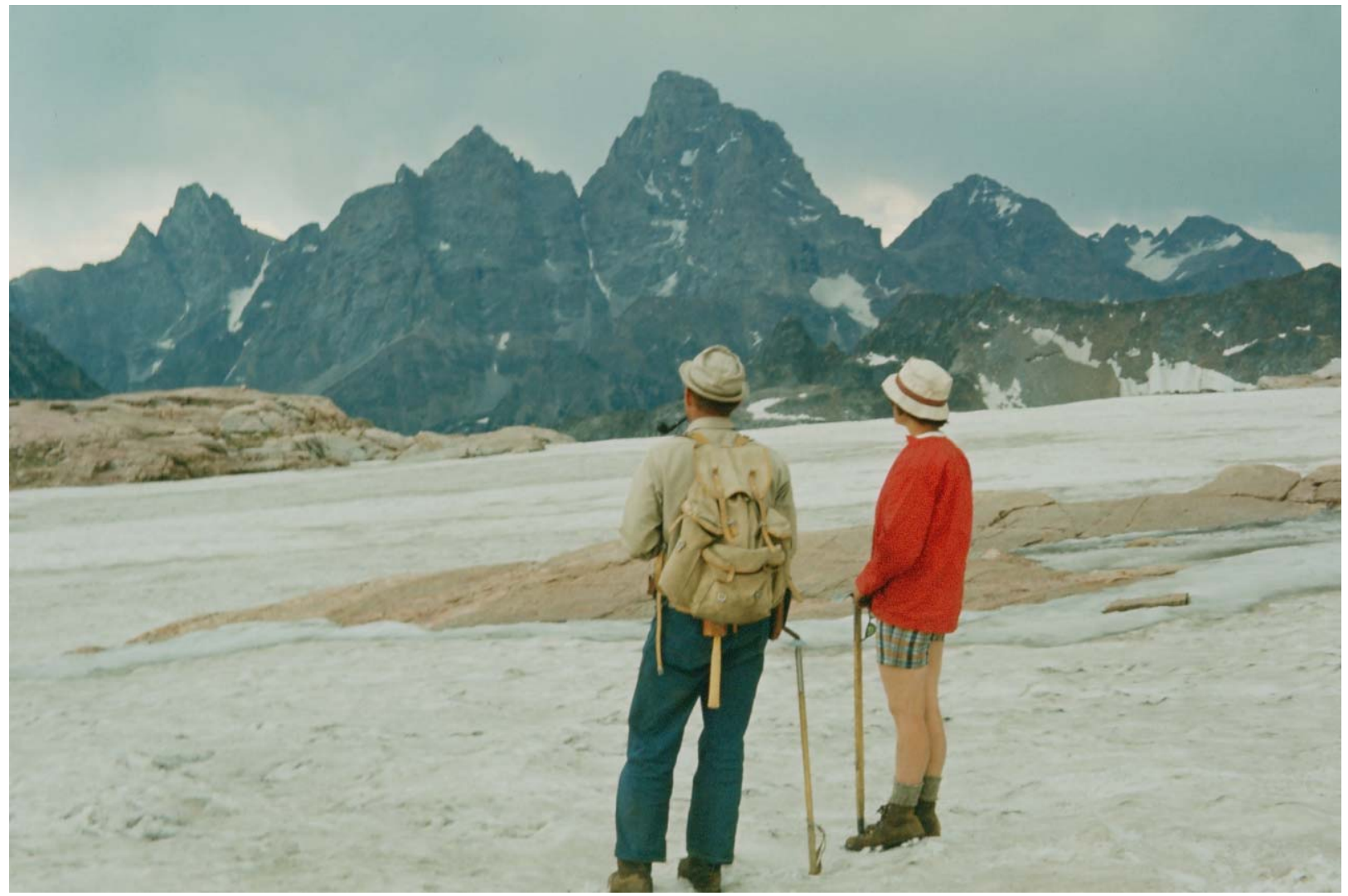

Figure 4. Jack and Linda Reed on the divide above Lake Solitude. 


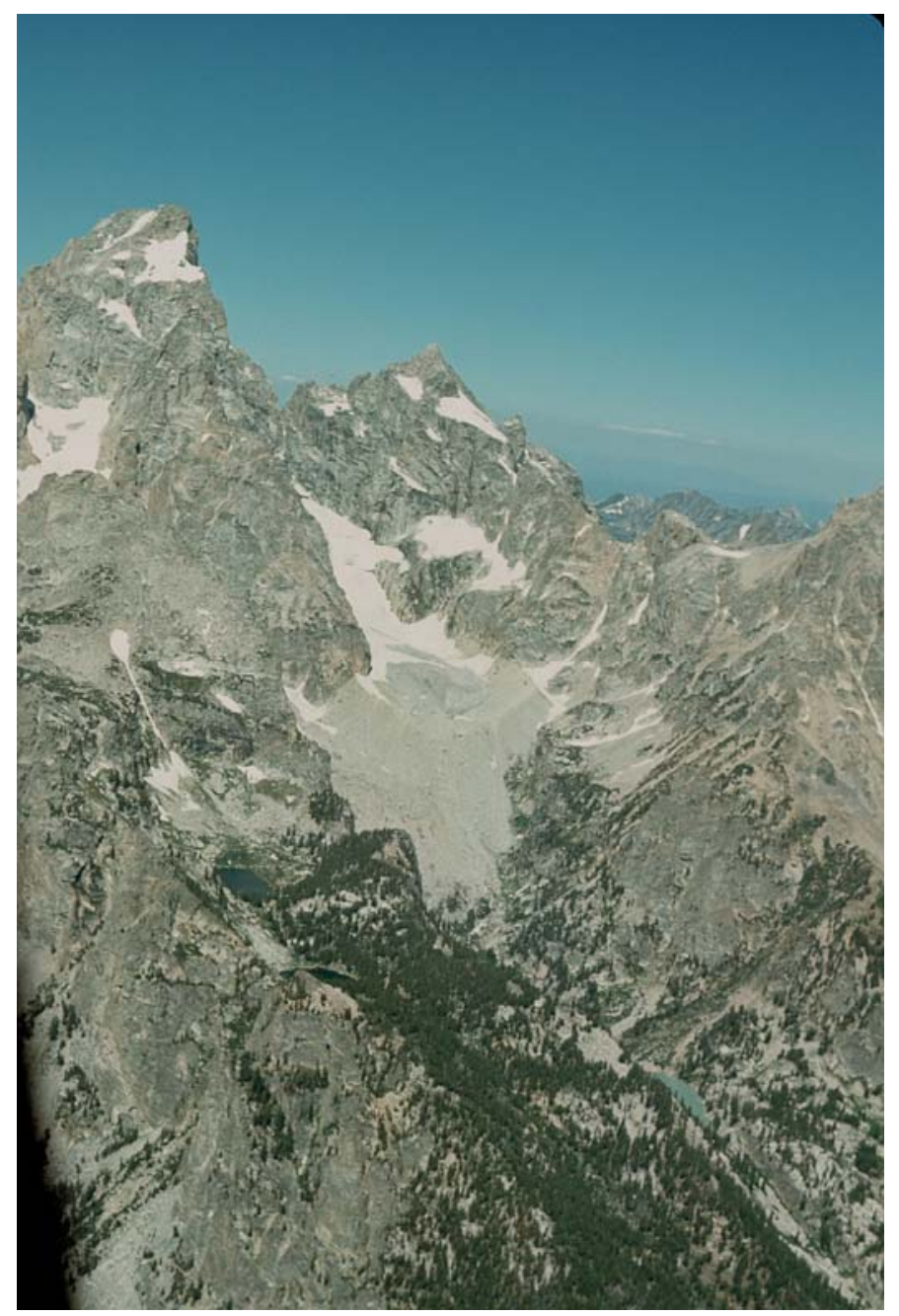

Figure 5. Aerial view of Teton Glacier photographed by Jack Reed in 1964.

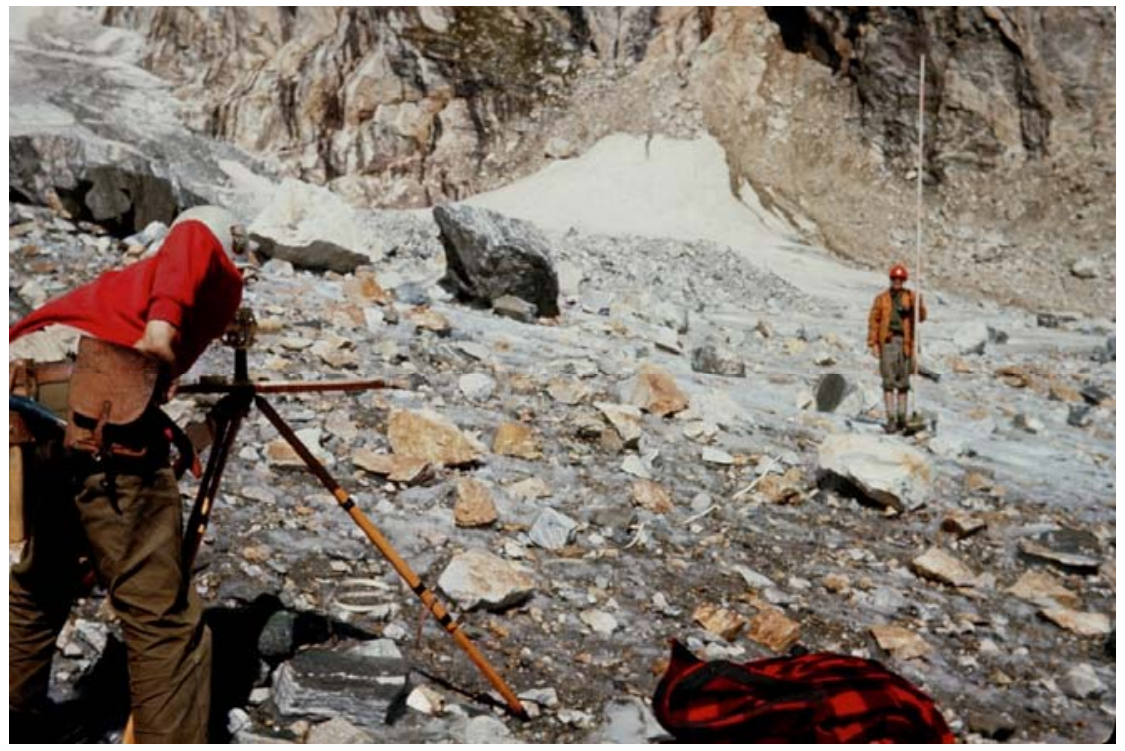

Figure 6. Reed's team surveying Teton Glacier. 


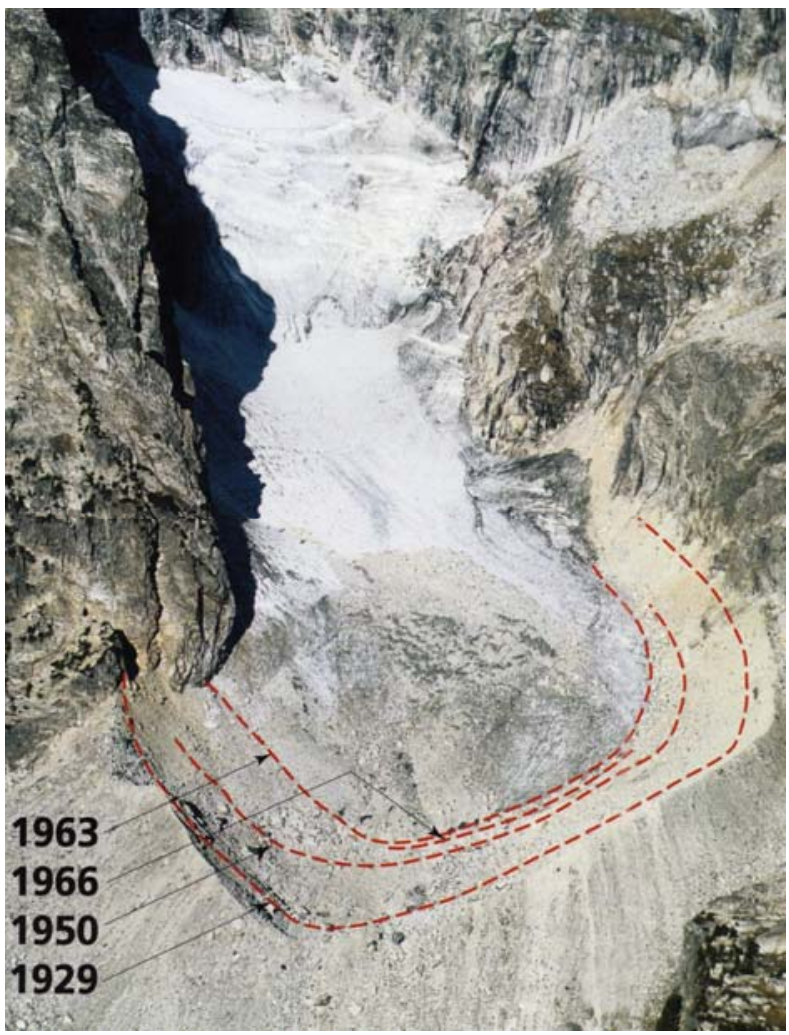

Figure 7. The extent of Teton Glacier as surveyed by Jack Reed in 1963 and 1966 compared to earlier years.

\section{$\downarrow \quad$ GEOLOGIC WORK IN THE TETONS, IN JACK REED'S WORDS}

In 1962, I was offered a chance to undertake a project in Wyoming's Teton Range. Dave Love, who was considered the dean of Wyoming geology, had been mapping in and around Jackson Hole for many years. He had requested someone to map the Precambrian rocks of the Teton Range for the geologic map of Grand Teton National Park that he was compiling. Would I like the job? Having done some climbing in the Tetons previously and having led a Colorado Mountain Club outing there in 1959, I jumped at the chance!

I began mapping in the Tetons in 1962 and made good progress for four field seasons (Figure 8, 9). But my idyll in the hills was rudely interrupted in 1965 by a summons back to D.C. to serve as chief of the Eastern States Branch. It was tough for the family to leave our mountain home in Colorado, but a wonderful chance for me to be introduced to the inner workings of a scientific bureaucracy.
I was paroled from my job as branch chief in spring 1969 and the family returned to Denver. That summer, USGS geologist Bob Zartman and I visited the Tetons and collected samples for radiometric dating. I spent much of the following winter learning the techniques of $\mathrm{Rb} / \mathrm{Sr}$ and $\mathrm{K} / \mathrm{Ar}$ dating in the laboratories of the Isotope Geology Branch in order to establish general ages on several of the major map units.

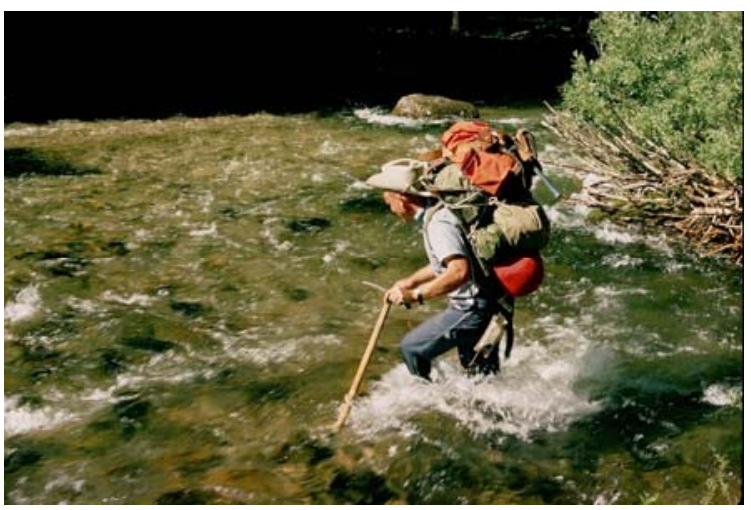

Figure 8. Jack Reed in the field, Teton Range. 


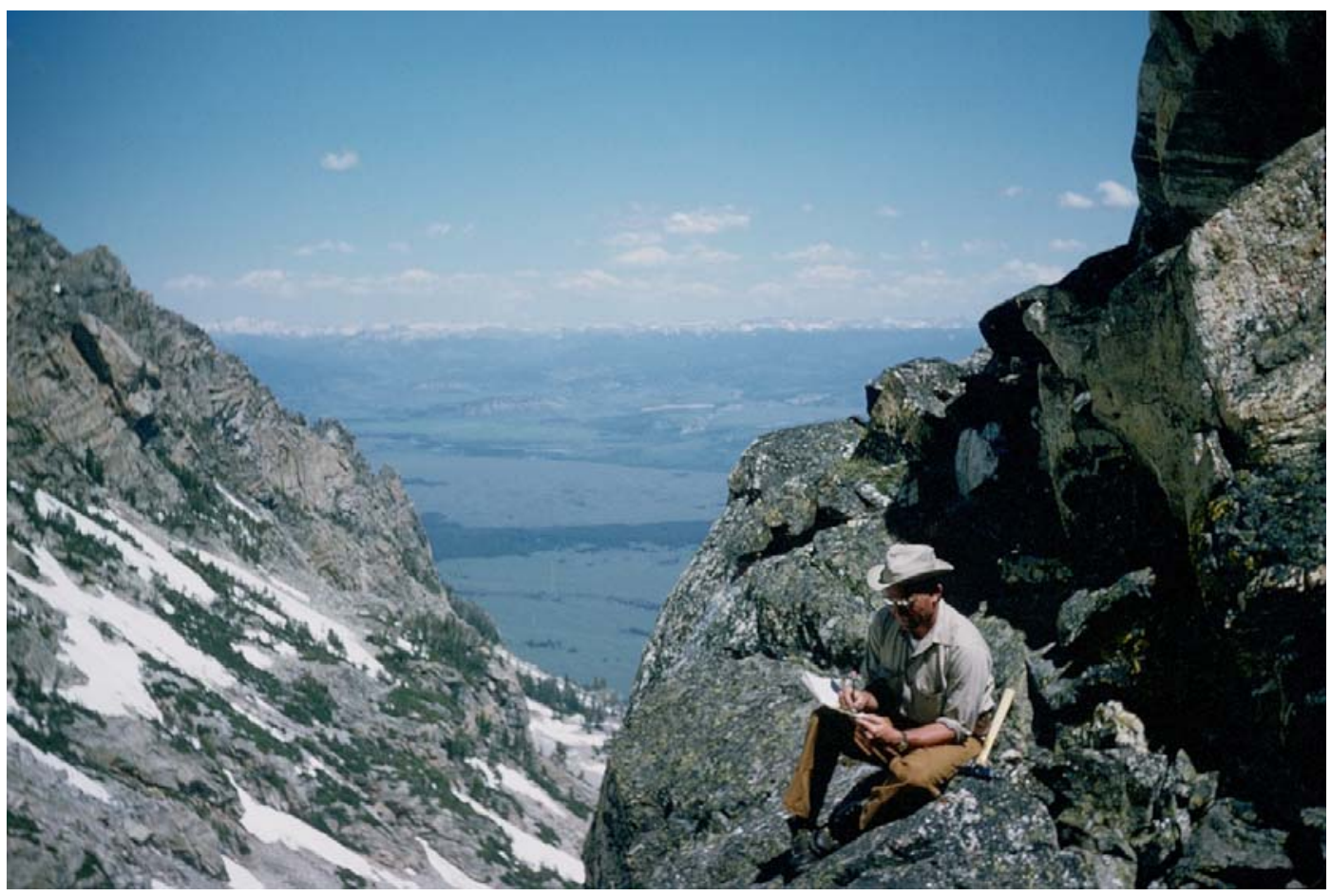

Figure 9. Jack Reed, reviewing field notes on the flanks of Symmetry Spire.

During the 1970 field season, I completed mapping on the west side of the Teton Range and began final compilation of my part of the Grand Teton National Park geologic map; however, because of delays in other segments of the project and the need to adjust our geologic mapping to a newly published topographic base, the map was not published until 1992.

Early in the Teton project, Dave Love had discussed compiling a general-interest book on the geologic story of the Tetons and Jackson Hole. Bill Dilley, then chief park naturalist, was extremely enthusiastic about the idea and indicated that the Grand Teton Natural History Association (now known as the Grand Teton Association) would be delighted to publish such a volume. I began work on the book in 1965 and continued as time allowed during my stint as branch chief and my subsequent work in the Tetons. Preparation of illustrations and ironing out various disagreements on content and style between the authors dragged on for several years, but the first edition of Creation of the Teton landscape: The geologic story of Grand Teton National Park was finally published in 1971. It was well received and has gone through at least a half-dozen printings.

\section{$\uparrow \quad$ SUMMARY}

Field geologist, mountaineer, and skilled scientific interpreter of the natural world: Jack Reed made foundational and enduring contributions to our understanding of the creation and evolution of the Teton landscape. The John C. Reed collection at University of Wyoming's American Heritage Center preserves his contributions and includes digital scans of Reed's field maps, field notes, and photographs, along with video interviews of Reed and his wife Linda made on location in Grand Teton National Park in July 2013.

\section{$\uparrow$ ACKNOWLEDGEMENTS}

In addition to support from the UW-NPS Research Station, this project would not have been possible without the expertise of videographer and editor James S. Costin of UW-TV, and digital collections manager Tyler Cline of the UW American Heritage Center. Thanks also go to Bridgette Guild, Museum Curator, Grant Teton National Park Science and Resource Management. 


\section{$\downarrow \quad$ LITERATURE CITED}

Bradley, C. C. 1956. The pre-Cambrian complex of Grand Teton National Park, Wyoming. pp. 34-42.

Bradley, F. H. 1873. Geological report of the Snake River Division. Annual Report of the US Geological Survey of the Territories (Hayden), 6th Annual Report. pp. 191-271.

Horberg, C. L., and F. M. Fryxell. 1941. Pre-Cambrian metasediments in Grand Teton National Park, Wyoming. American Journal of Science 240(6): 385-393.

Love, J. D., J. C. Reed Jr, and A. C. Christiansen. 1992. Geologic map of Grand Teton National Park, Teton County, Wyoming. No. 2031. US Geological Survey.

Ortenburger, L. N., and R. G. Jackson. 1996. A Climber's Guide to the Teton Range. The Mountaineers Books, Seattle, WA.

Reed Jr, J. C. 1963. Structure of Precambrian crystalline rocks in the northern part of Grand Teton National Park, Wyoming. Short papers in geology and hydrology. Professional Paper C1-C6, US Geological Survey.

Reed, J. C., Jr. 1996. Geology of the Teton Range. A Climber's Guide to the Teton Range, $3^{\text {rd }}$ ed. L. N. Ortenburger, and R. G. Jackson, (eds.) The Mountaineers Books, Seattle, WA.

Reed, J. C.. 1965. Rate of ice movement and estimated ice thickness in part of the Teton Glacier, Grand Teton National Park, Wyoming. US Geological Survey Professional Paper. pp. 137-141.

Reed, J. C. 1967. Observations on the Teton Glacier, Grand Teton National Park, Wyoming, 1965-1966. US Geological Survey Professional Paper 575: 154-159.

Reed, J. C., and R. E. Zartman. 1973. Geochronology of Precambrian rocks of the Teton Range, Wyoming. Geological Society of America Bulletin 84(2): 561-582.

St John, O. 1879. Report of the geological field work of the Teton division. Eleventh Annual Report of the US Geological and Geographical Survey of the Territories, Embracing Idaho and Wyoming.

Zartman, R. E., and J. C. Reed Jr. 1998. Zircon geochronology of the Webb Canyon Gneiss and the Mount Owen Quartz Monzonite, Teton Range, Wyoming: Significance to dating Late Archean metamorphism in the Wyoming craton. The Mountain Geologist.

\section{APPENDIX: PUBLICATIONS BY JOHN C. REED, JR., ON THE GEOLOGY OF THE TETONS}

Behrendt, J. C. 1968. A geophysical study in Grand Teton National Park and vicinity, Teton County, Wyoming, with sections on stratigraphy and structure by JD Love and Precambrian rocks by JC Reed. US Geological Survey Professional Paper E 516.

Reed Jr, John C. 1963. Structure of Precambrian crystalline rocks in the northern part of Grand Teton National Park, Wyoming. Short papers in geology and hydrology. United States Geological Survey, Professional Paper C1C6.

Reed Jr., John C. 1964. Recent retreat of the Teton Glacier, Grand Teton National Park, Wyoming. US Geological Survey.

Reed Jr., John C. 1965. Rate of ice movement and estimated ice thickness in part of the Teton Glacier, Grand Teton National Park, Wyoming. US Geological Survey, Professional Paper 137-141.

Reed Jr., John C. 1967. Observations on the Teton Glacier, Grand Teton National Park, Wyoming, 1965-1966. US Geological Survey, Professional Paper 575: 154-159.

Reed Jr, John C. 1966. Observations on the Teton Glacier, Grand Teton National Park, Wyoming. Geological Society of America Special Paper 300-301.

Love, John David, and John C. Reed Jr. 1968. Creation of the Teton landscape - the geologic story of Grand Teton National Park: Grand Teton Natural History Association.

Reed Jr., John Calvin, and John David Love. 1971. Preliminary geologic map of the Mount Bannon Quadrangle, Teton County, Wyoming. No. 71-233.

Anonymous (with John David Love, in part modified from F.M. Fryxell). 1971. Grand Teton National Park: U.S. Geological Survey Topographic Map text.

Reed Jr., John C., and R. E. Zartman. 1972. Geochronology of Precambrian rocks of the Teton Range, Wyoming. Geological Society of America Abstracts with Programs, v. 4(6): 403-404.

Reed Jr, John C., and John David Love. 1972. Preliminary geologic map of Granite Basin Quadrangle, Teton County, Wyoming. No. 72-309. 
Reed Jr., John C., and R. E. Zartman. 1972. Geochronology of Precambrian rocks of the Teton Range, Wyoming. Geological Society of America Abstracts with Programs, v. 4(7): 633-634.

Love, John David, et al. 1973. Geologic block diagram and tectonic history of the Teton region, Wyoming-Idaho. No. 730.

Love, John D., and J. C. Reed Jr. 1973. Preliminary geologic map of the Colter Bay Quadrangle, Teton County, Wyoming. No. 73-160.

Reed Jr, John Calvin., David W. Love, and J. D. Love. 1973. Preliminary geologic map of the Rammel Mountain Quadrangle, Teton County, Wyoming. No. 73-231.

Reed Jr., John C., and R. E. Zartman. 1973. Geochronology of Precambrian rocks of the Teton Range, Wyoming. Geological Society of America Bulletin 84.2: 561-582.

Love, John David, and John Calvin Reed Jr. 1975. Geologic Map of Teton Village Quadrangle, Teton County, Wyoming. No. 75-335.

Barker, F., H. T. Millard, and J. Reed Jr. 1976. Geochemistry of the Webb Canyon Gneiss, Teton Range, Wyoming: An Archean bimodal rhyodacite-tholeiite pair. Geol. Soc. Am. Abs. with Progr. 8: 568-569.

Reed Jr., John Calvin. 1973. Geologic map of the Precambrian rocks of the Teton Range, Wyoming. U.S. Geological Survey OpenFile Map, scale 1:24,000.

Christiansen, R. L., et al. 1978. Geologic map of the Grassy Lake Reservoir quadrangle. Yellowstone National Park and vicinity, Wyoming: US Geological Survey Geologic Quadrangle Map GQ-1459, scale 1.62,500.
Miller, S. H., et al. 1986. Metamorphic and deformation history of the gneiss complex in the northern Teton Range, Wyoming. 91109.

Reed Jr., John C. 1990. Aerial view of the Forellen Peak fault, northern Teton Range, Wyoming. Geology 18(9):807.

Love, John David, John C. Reed Jr, and Ann Coe Christiansen. 1992. Geologic map of Grand Teton National Park, Teton County, Wyoming. No. 2031.

Reed Jr, John C., and R. S. Houston. 1993. Teton and Gros Ventre Ranges, Pages 133-136 In: Reed, J.C., Jr., and others, (eds.), Precambrian-Conterminus U.S., in Geology of North America, v. C-2, Boulder, Geological Society of America, $657 \mathrm{pp}$.

Reed Jr., John C. 1996. Geology of the Teton Range, Pages 39-46 In: Ortenberberger, L., Climbers Guide to the Teton Range. The Mountaineers Press, Seattle 409 pp.

Zartman, Robert E., and John C. Reed Jr. 1998. Zircon geochronology of the Webb Canyon Gneiss and the Mount Owen Quartz Monzonite, Teton Range, Wyoming: Significance to dating Late Archean metamorphism in the Wyoming craton. The Mountain Geologist.

Love, J. D., J. C. Reed Jr, and K. L. Pierce. 2003. Creation of the Teton landscape. Grand Teton Natural History Association, Moose, Wyoming, 132pp.

Stacy, Sarah J., et al. 2009. Structural evidence of two Archean Terranes in the Teton Ranch, western Wyoming. Geological Society of America Abstracts with Programs, 41:6. 